\title{
PENCEGAHAN PENULARAN HIV IBU KE ANAK PADA ANTENATAL CARE DI KOTA DEPOK, JAWA BARAT
}

\author{
Ahmad Fachrul $^{1}$, Dewi Sri Astuti ${ }^{1}$ \\ ${ }^{1}$ Universitas Indonesia, Jl. Margonda Raya, Pondok Cina, Kecamatan Beji, Kota Depok, Jawa Barat \\ E-Mail:ahmadfachrul@ui.ac.id
}

\begin{abstract}
In 2018, Depok City AIDS prevalence was $23.75 \%$. ODHA has touched $72.6 \%$, based on age class $25-$ 49 years old peak. PMTCT programs was done to prevent HIV to infect children from their mother. This research was qualitative descriptive research which have implement grounded theory. This research was conducted in Independent Midwifery Clinic in Depok City on March-June 2019. Research subject was midwifes in Independent Midwifery Clinic, mother pregnancy patient of the Independent Midwifery Clinic, midwife coordinator of primary public health care center, and family health care sector in health care Department of Depok City. The first respondent has been taken a sample by snowball sampling. Research instrument was use manual interview and the data were collect with in depth interview. Data analysis is done using content analysis and data validation using triangle source. Research result is that PMTCT in ANC doesn't work effective in Independent Midwifery Clinic Depok City because PMTCT couldn't work their program without midwife and primary public health center. The mother pregnancy have been send to get Integrated ANC in primary public health center. Counseling and bargaining about HIV diagnostic. Cadre and all of public sector of this region can involved in this program.
\end{abstract}

Keywords: antenatal care, HIV, PPIA

Prevalensi AIDS di Kota Depok pada tahun 2018 adalah sebesar 23,75\%. Persentase penderita HIV/AIDS di Kota Depok berdasarkan golongan usia, yang tertinggi pada usia 25-49 tahun sebanyak $72,60 \%$. Kota Depok merupakan wilayah dengan jumlah ODHA tertinggi di Kota Depok. Program PPIA dilaksanakan untuk mencegah penularan HIV dari ibu ke anak. Penelitian ini dilakukan untuk mengetahui pelaksanaan PPIA pada ANC oleh bidan di Bidan Praktik Mandiri di Kota Depok. Jenis penelitian ini adalah kualitatif deskriptif dengan pendekatan grounded theory. Penelitian ini dilakukan di BPM di Kota Depok sejak bulan Maret-Juni 2019. Subjek penelitian adalah 5 bidan di Bidan Praktik Mandiri, pasien, bidang koordinator, dan sie Kesehatan Keluarga Dinas Kesehatan Kota Depok. Informan utama didapatkan dengan cara teknik snowball sampling. Instrumen penelitian adalah peneliti sendiri pedoman wawancara dan data dikumpulkan dengan cara in depth interview. Analisis data dilakukan dengan content analysis, keabsahan data dengan metode triangulasi sumber. Dari penelitian ini didapatkan bahwa PPIA pada ANC belum dilaksanakan secara maksimal di BPM di Kota Depok. Bidan berperan merujuk ibu hamil untuk mendapatkan ANC terpadu di puskesmas. Konseling dan penawaran tes HIV pada semua ibu hamil dapat menurunkan stigma dan diskriminasi di masyarakat. Pelaksanaan PPIA dapat melibatkan kader yang ada di wilayah dengan melibatkan semua lapisan masyarakat.

Kata Kunci: antenatal care terpadu, HIV, PPIA 


\section{INTRODUCTION}

Data dari United National Joint Programme for HIV and AIDS (2013) menyatakan bahwa pada tahun 2012 sekitar 35,3 juta orang di dunia hidup dengan HIV/ AIDS. Pada tahun yang sama jumlah kasus baru HIV di dunia mencapai 2,3 juta kasus dan kasus kematian karena AIDS mencapai 1,6 juta kasus. Menurut laporan Kemenkes RI (2013), sejak 1 Januari 2013 sampai dengan September 2013 kejadian HIV mencapai 20.413 orang. Kejadian tertinggi HIV terjadi pada kelompok usia 25-49 tahun dengan persentase $73,4 \%$. Perilaku seksual berisiko pada heteroseksual menjadi faktor risiko tertinggi yaitu sebesar 45,6\% untuk HIV dan 78,4\% untuk AIDS. Perbandingan jumlah penderita lakilaki dan perempuan adalah 1:1 untuk HIV dan 2:1 untuk AIDS.

Jumlah penderita HIV/ AIDS perempuan semakin bertambah seiring dengan meningkatnya penularan pada perilaku seksual tidak aman pada laki-laki yang kemudian menularkan HIV kepada pasangan seksualnya. Selain itu, penularan HIV dari ibu yang terinfeksi HIV kepada bayinya cenderung meningkat seiring dengan meningkatnya jumlah perempuan yang terinfeksi HIV. Pada triwulan III tahun 2013 yang menunjukkan faktor risiko penularan HIV dari ibu ke anak sebesar 4,3\%, meningkat 0,2\% dari laporan Kemenkes tentang HIV triwulan II tahun 2013. Penularan HIV dari ibu ke anak dapat tersebut dapat terjadi pada saat kehamilan, persalinan, dan menyusui.

Kementerian Kesehatan telah mengupayakan pencegahan penularan HIV/AIDS dari ibu ke anak sesuai rekomendasi WHO (2009) dengan menerbitkan Pedoman Pencegahan Penularan HIV dari Ibu ke Anak tahun 2012. PPIA merupakan salah satu upaya untuk mengendalikan HIV/AIDS dan Infeksi Menular Seksual (IMS) di Indonesia dan merupakan bagian dari program Kesehatan Ibu dan Anak (KIA). Program PPIA bertujuan untuk mengendalikan penularan HIV/AIDS, menurunkan kasus HIV serendah mungkin, mengurangi stigma dan diskriminasi, serta menurunkan kematian akibat AIDS (Getting to Zero). Program ini dapat dilaksanakan secara terintegrasi di setiap tingkatan layanan kesehatan dan dapat dilaksanakan oleh puskesmas dan jajarannya, rumah sakit, dan bidan praktik mandiri. Bidan dalam hal ini mempunyai peran yang sangat penting, dimana bidan berada di barisan terdepan dalam pelayanan kesehatan ibu dan anak. Meningkatnya penularan HIV dari ibu ke anak menyebabkan program PPIA harus segera dilaksanakan. Sesuai Pemodelan Matematik oleh Kementerian Kesehatan (2012), prevalensi HIV pada ibu hamil diproyeksikan akan meningkat dari 0,38\% pada tahun 2012 menjadi 0,49\% pada tahun 2016. Jumlah ibu hamil dengan HIV positif yang membutuhkan layanan PPIA akan meningkat dari 13.189 orang pada tahun 2012 menjadi 16.191 orang pada tahun 2016. Sejak Januari hingga September 2013, jumlah layanan PPIA yang dilaporkan di Indonesia adalah sebanyak 114 pelayanan dan telah melayani 4364 ibu hamil.

Angka AIDS caserate Kota Depok sampai dengan September 2018 adalah 18,3\% dan melebihi AIDS case rate nasional Indonesia yaitu sebesar 15,4\%. Prevalensi AIDS Kota Depok, yaitu jumlah penderita AIDS per 100.000 penduduk di Kota Depok adalah 23,75\% dan melebihi prevalensi nasional sebesar 4,54\%. Persentase penderita HIV/AIDS di Kota Depok berdasarkan golongan usia, 
yang tertinggi ada pada usia 25-49 tahun yaitu sebanyak 72,6\%. Kota Depok menjadi kabupaten/ kota dengan kasus baru Infeksi Menular Seksual (IMS) tertinggi dan kasus baru HIV/AIDS tertinggi kedua diantara lima kabupaten/ kota di Depok. Berdasarkan laporan Kementerian Kesehatan tentang HIV/ AIDS triwulan III tahun 2018, pelayanan PPIA di Kota Depok yang dilaporkan selama tahun 2018 (sampai bulan September 2018) hanya menjaring 12 ibu hamil.

Program PPIA harus segera dilaksanakan di seluruh layanan kesehatan agar penularan HIV dari ibu ke anak bisa dicegah sejak dini. Program PPIA diintegrasikan dalam pelayanan KIA, sehingga merupakan bagian dari tugas bidan di pelayanan KIA. Salah satu penyedia layanan KIA adalah Bidan Praktik Mandiri (BPM) tetapi PPIA belum dilaksanakan di Bidan Praktik Mandiri karena belum adanya protap yang mengatur pelaksanaan PPIA di Bidan Praktik Mandiri. Tujuan dari penelitian ini adalah bagaimana pelaksanaan PPIA saat ANC oleh bidan di Bidan Praktik Mandiri Kota Depok. Manfaat dari penelitian ini dapat menggambarkan pelaksanaan pelayanan PPIA pada pelayanan ANC oleh bidan di Bidan Praktik Mandiri di Kota Depok.

\section{METHOD}

Jenis penelitian ini adalah penelitian kualitatif deskriptif. Penelitian kualitatif dapat berarti memahami suatu fenomena tentang apa yang dialami subjek penelitian misalnya perilaku, persepsi, motivasi, tindakan, dan lain-lain. Secara holistik dan dengan cara deskripsi dalam bentuk kata-kata dan bahasa pada konteks khusus yang alamiah dan dengan memanfaatkan berbagai metode alamiah). Pendekatan dalam penelitian ini adalah grounded theory yang bermaksud untuk mengembangkan teori dari sebuah fenomena (Utarini, 2007). Penelitian ini menggunakan cara penelitian field research atau penelitian lapangan untuk mendapatkan data kualitatif. Peneliti berangkat ke lapangan untuk mengadakan pengamatan tentang sesuatu fenomena dalam suatu keadaan alamiah dan berkaitan erat dengan pengamatan-berperan serta.

Instrumen pengumpulan data pada penelitian ini adalah peneliti sendiri. Alat pengumpul data lainnya adalah pedoman wawancara, tape recorder, dan buku catatan. Peneliti menggunakan teknik snowball sampling untuk mendapatkan informan utama. Peneliti memilih informan pertama yang dianggap mampu menjelaskan dan menghubungkan peneliti dengan masalah yang ingin diteliti. Informan utama dalam penelitian ini adalah bidan di Bidan Praktik Mandiri. Bidan di BPM ini dipilih karena masalah yang diambil berhubungan dengan pelayanan KIA yaitu konseling HIV/AIDS dan penawaran tes HIV/AIDS pada pelayanan ANC. Dari informan pertama tersebut, peneliti meminta rekomendasi calon informan kedua yang dianggap dapat memberikan informasi pada peneliti. Informan selanjutnya dipilih berdasarkan rekomendasi informan sebelumnya. Selain bidan di BPM, informan dalam penelitian ini adalah ibu hamil yang ANC di BPM sebagai pihak yang menerima layanan dari bidan, bidan di puskesmas sebagai bidan koordinator di wilayah BPM dan petugas dinas kesehatan terkait. Jumlah informan tidak dibatasi sejak awal. Dalam penelitian ini, pengumpulan data dianggap cukup atau selesai apabila sudah tidak didapatkan variasi data, atau data 
dianggap sudah jenuh. Teknik analisis data yang digunakan adalah content analysis.

Pengecekan kebenaran/kredibilitas dalam penelitian ini adalah dengan triangulasi sumber. Menurut Moleong (2017), triangulasi sumber adalah melakukan pengecekan data melalui beberapa sumber. Data yang diambil dari informan utama yaitu bidan, di cek dengan mengumpulkan data dari ibu hamil yang ANC di BPM, pasien ANC di BPM, dan pemegang kebijakan yang diwakili oleh kepala puskesmas di wilayah BPM dan Kesehatan. Informasi dari informan utama yaitu bidan, dikonfrontasikan dengan jawaban dari pasien, kepala puskesmas, dan Dinas Kesehatan untuk mendapatkan kebenaran data.

\section{RESULTS AND DISCUSSION}

\section{Antenatal Care}

Hasil penelitian menunjukkan seluruh BPM di Kota Depok sudah melakukan ANC sesuai standar program pelayanan pemeriksaan ibu hamil atau antenatal care. Pemeriksaan ibu hamil yang dilakukan di BPM di Kota Depok meliputi timbang berat badan, ukur tekanan darah, ukur status gizi (dengan mengukur lingkar lengan atas), ukur tinggi fundus uteri, tentukan presentasi janin dan denyut jantung janin, skrinning status imunisasi tetanus dan lakukan imunisasi Tetanus Toksoid (TT) bila diperlukan, pemberian tablet zat besi minimal 90 tablet selama kehamilan, tes laboratorium rutin dan khusus, tatalaksana khusus, temu wicara (konseling), termasuk Perencanaan Persalinan dan Pencegahan Komplikasi (P4K) serta KB pasca persalinan. Tes laboratorium yang dilakukan di BPM hanya pemeriksaan $\mathrm{Hb}$ dan protein urin. Bidan merujuk pasien ke puskesmas ataupun laboratorium swasta untuk pemeriksaan laboratorium khusus meliputi tes IMS, HbsAg dan HIV.

ANC terpadu belum dapat dilakukan di semua puskesmas. Pelayanan ANC terpadu yang belum dilakukan di semua puskesmas dikarenakan beberapa hal terkait fasilitas dan kemampuan petugas. Hal ini sesuai dengan penelitian Mikrajab (2015) yang menunjukkan masih belum maksimalnya peran pemegang kebijakan dalam menjembatani pelayanan ANC terpadu. Pelatihan dan peningkatan kapasitas secara berkala bagi petugas pemberi pelayanan ANC terpadu yang terdiri dari bidan untuk pemeriksaan fisik dan konseling, serta analis/petugas lab terkait pemeriksaan laboratorium rutin dan atas indikasi medis. Selain kemampuan sumber daya manusia, ketersediaan logistik yang menunjang pemeriksaan lab untuk HIV belum tersedia maksimal. Hanya beberapa puskesmas di Kota Depok yang memiliki laboratorium yang mendukung.

Kerja sama lintas sektoral para aktor kebijakan di daerah dalam implementasi ANC terpadu Puskesmas masih rendah dan berjalan secara parsial. Hal ini menyebabkan belum memadainya ketersediaan fasilitas laboratorium dan USG untuk pemeriksaan ibu hamil di beberapa wilayah sehingga belum maksimalnya pelayanan ANC terpadu. Peraturan daerah terkait pemeriksaan lab rutin dan atas indikasi medis belum berpihak pada ibu hamil yang tidak mampu/miskin. 


\section{Pencegahan Penularan HIV dari Ibu ke Anak}

Wudineh (2016) menyatakan pencegahan penularan HIV dari ibu ke anak merupakan program yang semakin menjadi perhatian seiring meningkatnya kejadian HIV pada ibu dan anak. Dengan intervensi yang baik maka risiko penularan HIV dari ibu ke bayi sebesar 25\% hingga $45 \%$ bisa ditekan menjadi kurang dari 2\%. Pelaksanaan PPIA pada pelayanan kesehatan ibu dan anak dapat menurunkan angka kematian pada ibu HIV. Pelayanan Bidan Praktik Mandiri merupakan salah satu fasilitas pelayanan kesehatan ibu dan anak yang ada di Indonesia. Bidan Praktik Mandiri merupakan tempat pelayanan dasar yang menjadi lini pertama deteksi dini terhadap komplikasi pada kehamilan termasuk HIV.

Penelitian Ariningtyas (2017) menyatakan bahwa pelaksanaan PPIA pada pelayanan kesehatan ibu dan anak dapat menurunkan angka kematian pada ibu HIV. Pelayanan Bidan Praktik Mandiri merupakan salah satu fasilitas pelayanan kesehatan ibu dan anak yang ada di Indonesia. Program PPIA sebagai program pencegahan HIV dari ibu ke anak sebagian besar dapat dilakukan oleh bidan. Bidan dapat memberikan konseling dan dukungan pada perempuan yang tidak terinfeksi HIV maupun yang sudah terinfeksi HIV. Penelitian ini menunjukkan bahwa bidan BPM di kota Depok merujuk seluruh ibu hamil ke semua puskesmas untuk mendapatkan pelayanan ANC terpadu yang mencakup PPIA di dalamnya. PPIA pada ibu hamil terintegrasi dalam ANC terpadu yaitu dalam konseling HIV dan penawaran tes HIV pada semua ibu hamil. Ibu hamil wajib melakukan pemeriksaan kehamilan di puskesmas minimal 1 kali dari kunjungan ANC ibu hamil ke tenaga kesehatan.

Pelaksanaan PPIA dalam ANC terpadu yang tidak dapat dilaksanakan di BPM disebabkan oleh beberapa hal. Sebab tersebut diantaranya adalah kemampuan bidan dalam konseling HIV belum mencukupi, dan kebanyakan bidan merasa kurang mampu menjelaskan pada pasien tentang pemeriksaan HIV ini. Bidan mengetahui mengenai sosialisasi HIV dan AIDS pada ibu hamil dari pelatihan dan sosialisasi yang telah diikuti. Bidan yang sudah mendapatkan pelatihan PPIA wajib melakukan sosialisasi kepada bidan yang belum mendapatkan kesempatan untuk pelatihan, hal ini dilakukan agar semua bidan mendapat pengetahuan dan dapat melakukan sosialisasi HIV dan AIDS juga PPIA ke setiap ibu hamil yang datang (Widiyasari et al., 2014).

Pencegahan penularan HIV dari ibu ke anak pada ibu hamil yang termasuk dalam pelayanan ANC terpadu baru mulai dilaksanakan tahun 2019. Hal ini tidak sesuai dengan program PPIA yang mulai diadakan tahun 2017 dan surat edaran menteri kesehatan pada tahun 2019. Dinas kesehatan Kota Depok yakin bahwa pada tahun 2019 ini dapat mencakup sasaran ibu hamil yang dites yaitu sebesar 35\%. Diharapkan puskesmas dengan Layanan Komprehensif Berkelanjutan (LKB) dapat menutup pencapaian target puskesmas non LKB yang belum sesuai target. Peningkatan pencapaian puskesmas melaksanakan program PPIA tidak lepas dari peran bidan. Puskesmas perlu melakukan koordinasi pada BPM di wilayah kerjanya agar merujuk pasiennya terutama ibu hamil untuk menjalani program PPIA di puskesmas. 
Tabel 1. Program PPIA Penanggulangan HIV

\begin{tabular}{|c|c|c|c|}
\hline \multirow[t]{2}{*}{ Program PPIA } & \multirow[t]{2}{*}{ Kegiatan } & \multicolumn{2}{|c|}{ Pelaksanaan } \\
\hline & & Sesudah & Sebelum \\
\hline \multirow[t]{2}{*}{$\begin{array}{l}\text { Pencegahan penularan } \\
\text { HIV pada perempuan } \\
\text { usia reproduksi }\end{array}$} & $\begin{array}{l}\text { Menyebarluaskan komunikasi, } \\
\text { Informasi dan Edukasi (KIE) } \\
\text { tentang HIV-AIDS dan } \\
\text { Kesehatan Reproduksi secara } \\
\text { individu maupun kelompok }\end{array}$ & $\begin{array}{l}\text { Sudah dilakukan } \\
\text { oleh sebagian } \\
\text { bidan bekerja } \\
\text { sama dengan } \\
\text { puskesmas dan } \\
\text { LSM }\end{array}$ & $\begin{array}{l}\text { Sebagianbidan } \\
\text { belum } \\
\text { melaksanakan }\end{array}$ \\
\hline & $\begin{array}{l}\text { Mobilisasi masyarakat yang } \\
\text { melibatkan petugas lapangan } \\
\text { dan masyarakat }\end{array}$ & $\begin{array}{l}\text { Sebagian sudah } \\
\text { melaksanakan, } \\
\text { melibatkan kader } \\
\text { ibu hamil di } \\
\text { Kota Depok }\end{array}$ & $\begin{array}{l}\text { Sebagian belum } \\
\text { melaksanakan }\end{array}$ \\
\hline \multirow{2}{*}{$\begin{array}{l}\text { Pencegahan } \\
\text { kehamilan tidak } \\
\text { diinginkan dan } \\
\text { perencanaan } \\
\text { kehamilan pada } \\
\text { perempuan yang } \\
\text { terinfeksi HIV }\end{array}$} & $\begin{array}{l}\text { Konseling dan penyediaan } \\
\text { kontrasepsi yang aman dan } \\
\text { efektif }\end{array}$ & $\begin{array}{l}\text { Semua bidan } \\
\text { menyediakan alat } \\
\text { kontrasepsi } \\
\text { kondom }\end{array}$ & \\
\hline & $\begin{array}{l}\text { Penyampaian informasi } \\
\text { kondom sebagai alat } \\
\text { pencegahan penularan HIV }\end{array}$ & $\begin{array}{l}\text { Beberapa bidan } \\
\text { menyampaikan } \\
\text { informasi } \\
\text { tentang alat } \\
\text { pencegahan HIV }\end{array}$ & $\begin{array}{l}\text { Beberapa bidan } \\
\text { tidak } \\
\text { menyampaikan info } \\
\text { tentang HIV }\end{array}$ \\
\hline \multirow[t]{5}{*}{$\begin{array}{l}\text { Pencegahan penularan } \\
\text { HIV dari ibu hamil } \\
\text { dengan HIV ke bayi } \\
\text { yang dikandungnya }\end{array}$} & Pelayanan antenatal terpadu & & $\begin{array}{l}\text { Semua bidan } \\
\text { belum } \\
\text { melaksanakan } \\
\text { ANC terpadu di } \\
\text { BPM }\end{array}$ \\
\hline & $\begin{array}{l}\text { Skrining atau diagnosis dan } \\
\text { tatalaksana IMS, HIV, TB, dan } \\
\text { malariapada ibu hamil }\end{array}$ & & $\begin{array}{l}\text { Semua bidan } \\
\text { belum } \\
\text { melaksanakan tes } \\
\text { HIV di BPM }\end{array}$ \\
\hline & $\begin{array}{l}\text { Pemberian ARV sesuai kriteria } \\
\text { eligible ARV }\end{array}$ & & $\begin{array}{l}\text { Semua bidan } \\
\text { belum memberikan } \\
\text { ARV di BPM }\end{array}$ \\
\hline & Perencanaan persalinan Aman & $\begin{array}{l}\text { Bidan melakukan } \\
\text { Pencegahan } \\
\text { Infeksi untuk } \\
\text { mencegah } \\
\text { penularan } \\
\text { pada Bidan }\end{array}$ & \\
\hline & $\begin{array}{l}\text { Konseling menyusi atau } \\
\text { pemberian makanan untuk bayi }\end{array}$ & & $\begin{array}{l}\text { Bidan belum } \\
\text { memberi konseling } \\
\text { pemberian } \\
\text { makanan untuk } \\
\text { bayi }\end{array}$ \\
\hline $\begin{array}{l}\text { Dukungan psiko-sosial } \\
\text { bagi ibu yang } \\
\text { terinfeksi HIV }\end{array}$ & $\begin{array}{lrr}\text { Penyuluhan } & \text { kepada } & \text { anggota } \\
\text { keluarga } & \text { tentang } & \text { cara } \\
\text { penularan } & \text { HIV } & \text { dan } \\
\text { pencegahannya } & \text { serta } \\
\text { penggerakan } & \text { dukungan } \\
\text { masyarakat bagi } & \text { keluarga } \\
\text { dengan atau terdampak HIV }\end{array}$ & & $\begin{array}{l}\text { Bidan belum } \\
\text { melaksanakan }\end{array}$ \\
\hline
\end{tabular}


Kegiatan PPIA yang dilaksanakan melalui kegiatan komprehensif di Bidan Praktik Mandiri di Kota Depok yang meliputi 4 pilar (prong) yaitu:

Tabel 1 menunjukkan beberapa kegiatan dari setiap prong PPIA belum dilaksanakan secara maksimal oleh bidan di Bidan Praktik Mandiri. Beberapa kegiatan dalam program PPIA mengharuskan bidan berkolaborasi dengan tenaga kesehatan lain dan fasilitas kesehatan yang lebih tinggi. Hal ini berguna agar program PPIA yang komprehensif dapat dilaksanakan. Bidan mempunyai keterbatasan dalam praktiknya sebagai fasilitas pelayanan kesehatan ibu dan anak. Namun, dengan keterbatasan tersebut bidan tetap dituntut untuk melakukan program PPIA di tempat praktiknya. Dukungan bidan sebagai petugas kesehatan juga dapat dilaksanakan untuk memberikan edukasi pada masyarakat umum dan keluarga pasien. Sampai saat ini, budaya masyarakat di Indonesia masih menganggap bidan sebagai tokoh masyarakat yang sangat dipercaya. Penelitian ini menunjukkan alasan bidan tidak melaksanakan program PPIA di Bidan Praktik Mandiri yang dimilikinya. PPIA belum dilaksanakan di semua Bidan Praktik Mandiri. Bidan yang tidak melaksanakan PPIA dipengaruhi oleh beberapa alasan seperti yang tergambar dalam matriks Gambar 1.

Kegiatan PPIA dilaksanakan melalui kegiatan komprehensif yang meliputi 4 pilar (prong) yaitu sebagai berikut: Pertama, pencegahan HIV pada perempuan usia reproduktif. Upaya pencegahan dalam tahap ini adalah dengan meningkatkan pengetahuan HIV pada perempuan. Penelitian Wahyuni (2017) menyatakan bahwa masyarakat dengan pengetahuan tentang HIV yang buruk akan meningkatkan stigma dan diskriminasi pada ODHA. 


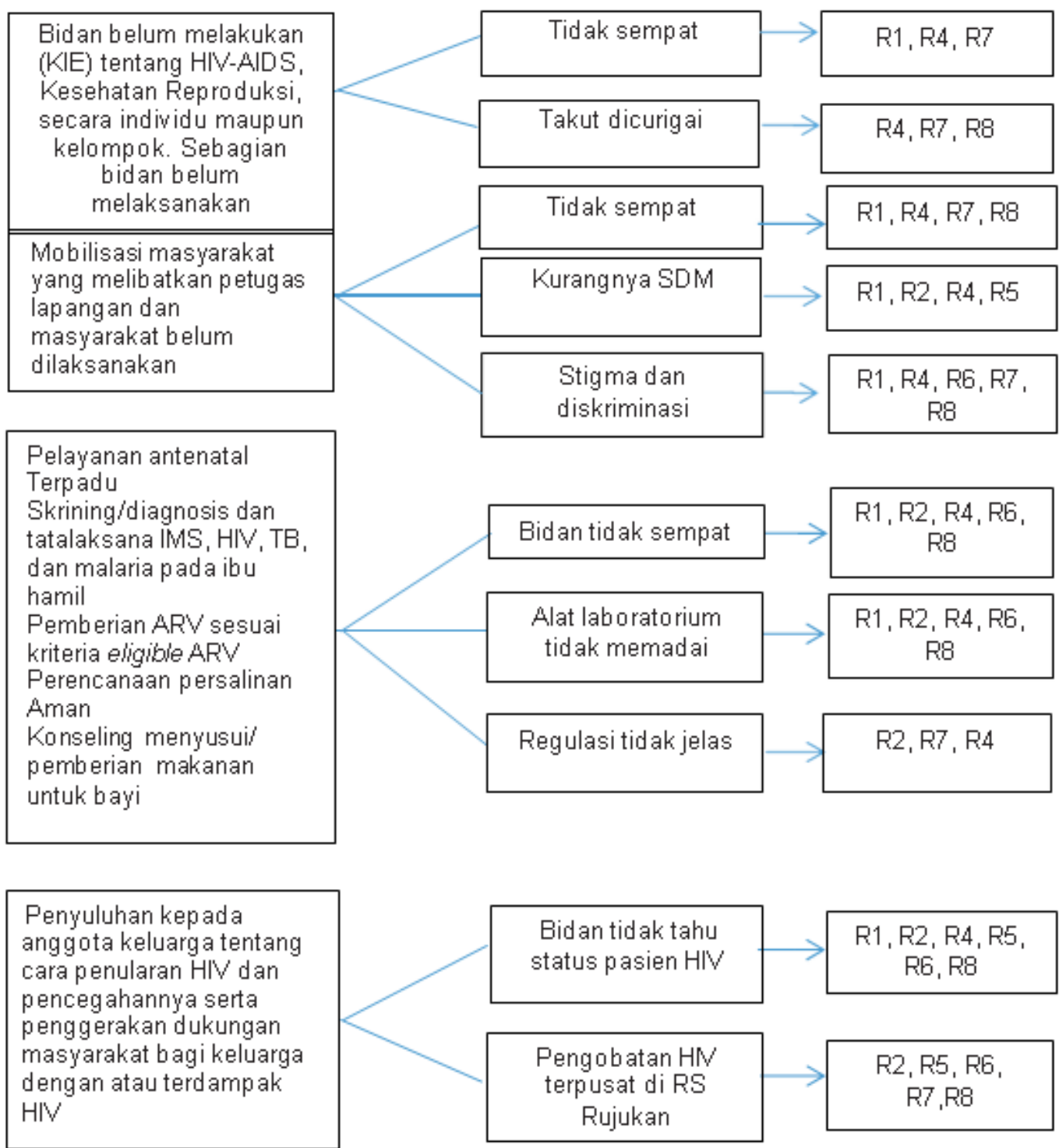

Gambar 1. Matriks Ketidak Berlangsungan Promgram PPIA

Puskesmas di kota Depok secara berkala melakukan penyuluhan tentang IMS dan HIV kepada masyarakat di wilayah kerjanya. Puskesmas melakukan penyuluhan di perkumpulan remaja, ibu-ibu PKK dan sekolah. Bidan di BPM juga di imbau untuk melakukan penyuluhan secara mandiri. Salah satu cara yang dipakai puskesmas untuk meningkatkan keterlibatan bidan di BPM adalah dengan mengajak bidan BPM dalam penyuluhan yang dilakukan puskesmas. Media untuk penyuluhan yang digunakan berupa leaflet, poster, buku saku, dan iklan layanan masyarakat di televisi ataupun radio. Dengan semakin banyaknya pengenalan tentang HIV pada masyarakat, stigma dan diskriminasi tentang HIV di masyarakat mulai berkurang. Namun, ada juga bidan yang menemui masyarakat yang masih menganggap HIV tabu, karena mereka menganggap itu adalah penyakit memalukan dan aib.

Kedua, pencegahan kehamilan tidak direncanakan pada perempuan HIV. Pencegahan dapat dilakukan dengan metode kontrasepsi "double protection" dan kondom. Penderita HIV yang menggunakan kontrasepsi double protection masih rendah. Kebanyakan penderita hanya menggunakan 
kondom sebagai upaya pencegahan (Aini, 2017). Upaya pencegahan penularan HIV dari hubungan seksual salah satunya dengan kondom. Kondom dapat diakses secara gratis di beberapa kantong pelayanan, misalnya puskesmas, Perkumpulan Keluarga Berencana Indonesia (PKBI), dan RSUP Sardjito. Namun, sosialisasi tentang upaya pencegahan HIV dengan kondom sering menemui kendala, misalnya ketika akan dilakukan penyuluhan ke sekolah, penyuluh ditolak oleh guru karena dianggap akan memicu seks bebas pada remaja.

Ketiga, Pencegahan penularan dari Ibu hamil dengan HIV ke bayi yang dikandungnya. Penelitian yang dilakukan oleh Liem \&Adriyanti (2013) menyatakan bahwa bidan di puskesmas berperan dalam pencegahan penularan HIV dari ibu hamil ke bayi. Komunikasi dan pembinaan psikologi yang dilakukan bidan menyebabkan hal tersebut. Peran bidan sangat penting saat pelayanan ANC. Seluruh BPM sudah merujuk pasiennya ke puskesmas untuk mendapatkan pelayanan ANC terpadu yang dilaksanakan di puskesmas. Puskesmas yang bukan merupakan puskesmas LKB harus merujuk ke puskesmas LKB. Hal ini dikarenakan puskesmas non LKB belum memiliki pelayanan labratorium lengkap meliputi tes HIV dan HbsAg. Pada tahun 2014 ini, rujukan antar puskesmas, yang dirujuk adalah specimen darah ibu.

Semua ibu hamil yang mendapat pelayanan ANC terpadu, mendapatkan tes HIV untuk mendiagnosa HIV. Tes HIV yang digunakan adalah tes ELISA. Salah satu hambatan tidak terlaksananya tes HIV pada semua ibu hamil adalah karena reagen ini tidak tersedia dalam jumlah cukup pada tahun 2019. Namun pada tahun 2020, reagen yang disediakan akan mencukupi untuk target ibu hamil sebanyak 35\% dari seluruh ibu hamil di Kota Depok. Pengobatan anti retroviral bisa didapatkan di rumah sakit rujukan di Kota Depok. Pasien dari puskesmas yang terinfeksi HIV akan dirujuk ke RS tersebut dengan didampingi konselor dan pendamping pasien (dari LSM). Pasien HIV akan mendapatkan rujukan dari puskesmas. Rujukan vertikal yang diberikan pada penderita HIV merupakan rujukan vertikal supaya pasien mendapatkan perawatan spesialistik dan dikarenakan terbatasnya fasilitas puskesmas (Ratnasari, 2017).

Hasil dari tes HIV tidak akan dibuka tanpa persetujuan pasien. Namun, dalam buku KIA sudah disepakati kode untuk pemeriksaan HIV, yaitu PITC R untuk reaktif dan PITC NR untuk yang non reaktif. Jadi kode ini akan bermanfaat bagi tenaga kesehatan untuk melindungi diri dari penularan HIV dan bisa menerapkan pencegahan infeksi dengan benar. Petugas kesehatan yang menjelaskan mengenai pemberian makanan bagi bayi dan anak serta mendeteksi HIV pada ibu hamil akan bermanfaat untuk mencegah penularan HIV pada anak. Bidan di BPM tidak pernah memberikan konseling kepada ibu HIV tentang makanan pada bayi dan anak, karena selama ini bidan tidak mengetahui status pasien jika pasien tidak membuka statusnya. Pelaksanaan ANC harus mendapat dukungan dari keluarga. Hal ini sejalan dengan penelitian Halim et al (2016) yang menyatakan bahwa keterlibatan suami dipengaruhi oleh komponen yang sangat penting untuk pelayanan ANC, terutama untuk meningkatkan strategi upaya pencegahan penularan HIV dari ibu ke bayi.

Keempat, dukungan psikologis, sosial, dan perawatan kesehatan selanjutnya kepada ibu yang 
terinfeksi HIV dan bayi serta keluarganya. Sebagian bidan BPM belum melakukan dukungan terhadap ibu atau bayi yang terinfeksi HIV. Perawatan terhadap Ibu yang mengidap HIV dilakukan di rumah sakit. Bidan di BPM tidak menangani langsung. Bidan hanya bisa memberikan dukungan pada ibu jika ibu membuka statusnya pada bidan. Selain itu, perawatan terhadap penderita HIV terpusat di rumah sakit besar. Peran dukungan bidan sejalan dengan penelitian yang dilakukan Isni (2016) yang menyatakan masih terdapat petugas kesehatan yang tidak mendukung ibu HIV positif dalam upaya mencegah penularan HIV ke bayi, termasuk ketika petugas kesehatan tidak bersedia dihubungi melalui telepon selular oleh responden apabila responden membutuhkan informasi atau bantuan Penelitian Okoli (2014), menyebutkan pula bahwa peran tenaga kesehatan dalam memberi dukungan dan perawatan kepada pasien HIV menentukan kesuksesan program PPIA. Tenaga kesehatan dapat menggandeng LSM dan kader ibu hamil dalam memberikan dukungan kepada penderita HIV.

\section{Hambatan dalam Pelaksanaan PPIA}

Sebagian responden mengatakan bahwa tidak ada hambatan dalam merujuk pasien dan memberi pasien konseling dan menawarkan tes HIV pada pasien. Sebagian responden mengatakan bahwa BPM belum mampu melaksanakan PPIA terutama ANC terpadu. Hambatan dalam pelaksanaan PPIA adalah sebagian dari responden mengatakan bahwa tidak ada hambatan dalam merujuk pasien dan memberi pasien konseling dan menawarkan tes HIV pada pasien. Program PPIA pada ibu hamil yaitu dalam ANC terpadu dalam bentuk konseling penawaran tes HIV saat ini belum dapat dilaksanakan dengan maksimal baik di puskesmas maupun BPM. Hal ini disebabkan oleh keterbatasan reagen dan alat laboratorium pada tahun 2019. Ketersediaan reagen untuk tes HIV masih terbatas sehingga cakupan ibu hamil yang dilakukan tes tidak banyak, serta diprioritaskan bagi yang ibu hamil yang dicurigai HIV atau berisiko tinggi.

\section{CONCLUSION}

Bidan di Bidan Praktik Mandiri belum melaksanakan PPIA dalam ANC terpadu secara maksimal karena ANC terpadu tidak bisa dilaksanakan di BPM. Peran bidan dalam ANC terpadu adalah mengarahkan ibu hamil untuk melakukan ANC terpadu di puskesmas sedangkan bidan di BPM dapat memberikan konseling HIV dan penawaran tes HIV pada semua ibu hamil. Konseling dan penawaran tes HIV pada semua ibu hamil dapat menurunkan stigma dan diskriminasi masyarakat. Saat ini stigma dan diskriminasi dari masyarakat tentang HIV sudah mulai berkurang. Semua ibu hamil harus dilakukan PICT agar petugas kesehatan dapat mengetahui status pasien sehingga dapat memberikan pelayanan kesehatan secara tepat. Apabila diketahui status HIV pada ibu hamil, maka risiko penularan HIV dari Ibu ke Anak saat kehamilan maupun persalinan dapat dicegah. Bidan di Bidan Praktik Mandiri belum melakukan penyuluhan tentang kesehatan reproduksi, infeksi menular seksual dan HIV pada masyarakat. Bagi Bidan di Bidan Praktik Mandiri disarankan untuk melakukan konseling dan penawaran tes HIV untuk ANC terpadu. Informasi mengenai HIV dapat mengurangi 
stigma dan diskriminasi pada penderita HIV dan AIDS. Peningkatan pengetahuan ini dapat dilakukan melalui media sosial maupun bekerja sama dengan berbagai LSM maupun puskesmas. Bagi dinas kesehatan untuk membuat regulasi yang jelas tentang PPIA, mengadakan pelatihan.

\section{ACKNOWLEDGMENTS}

Ucapan terimakasih kepada pihak-pihak terkait terutama pada Dinas Kesehatan Kota Depok, Puskesmas di Wilayah Kota Depok dan Rumah Sakit Rujukan di Kota Depok.

\section{REFERENCES}

Aini, L.N. 2017. Pilihan Kontrasepsi Perempuan Penderita HIV. Midwifery Science Journal, 1(1), pp. $130-41$.

Ariningtyas, N. 2017. Kendala Program PPIA pada Antenatal Care. Jurnal Kesehatan Samudra Ilmu, 8.

Ditjen PP \& PL. 2014. Statistik HIV AIDS di Indonesia. Jakarta: aidsindonesia.or.id.

Halim, Y..S.B.\&.K.A.. 2016. Faktor-faktor yang Berhubungan dengan Perilaku Ibu Hamil dalam Pemeriksaan HIV di Wilayah Kerja Puskesmas Halmahera Kota Semarang. Jurnal Kesehatan Masyarakat (e-Journal), 4(5), pp. 395-405.

Isni, K. 2016. Dukungan Keluarga, Dukungan Petugas Kesehatan dan Perilaku Ibu HIV dalam Pencegahan Penularan HIV/AIDS dari Ibu ke Bayi. Jurnal Kesehatan Masyarakat, 11(2), pp. 96-104.

Kemenkes RI. 2012. Pedoman Pencegahan Penularan HIV dari Ibu ke Anak. Jakarta: Kemenkes RI.

Liem, A. \& Adiyanti, M.J. 2013. Bidan Cantik: Psychoeducation on HIV and AIDS to Improve the Service Quality of Midwifes at Yogyakarta Pulic Health Center. HIV and AIDS Review, 12(1), pp. 1-28.

Mikrajab, M.A. \& Rachmawati, T. 2016. Analisis Kebijakan Implementasi Antenatal Care Terpadu Puskesmas di Kota Blitar. Buletin Penelitian Sistem Kesehatan, 19(1), pp. 42-53.

Moleong, L.J. 2017. Metodologi Penelitian Kualitatif.Bandung: Rosdakarya.

Okoli, J.C. \& Lansdown, G.E. 2014. Barriers to Successful Implementation of Prevention-ofMother-to-Child-Transmission (PMTCT) of HIV Programmes in Malawi and Nigeria: a Critical Literature Review Study. Pan Afr Med J, 19, p. 154. 
Ratnasari, D. 2017. Analisis Pelaksanaan Sistem Rujukan Berjenjang Bagi Peserta JKN di Puskesmas X Kota Surabaya. Jurnal Administrasi Kesehatan Indonesia, 5 (2).

United Nation Joint Programme for HIV and AIDS. 2013. Global Report. unaids.org.

Utarini, A. 2007. Metode Penelitian Kualitatif di Bidang Kesehatan. Yogyakarta: FK UGM.

Wahyuni, S. 2017. Hubungan antara Pengetahuan HIV/ AIDS dengan Sikap Penolakan terhadap Penderita HIV. Jurnal Kesehatan Reproduksi, 8(1), pp. 41-52.

WHO. 2009. Pelayanan Kesehatan Anak di Rumah Sakit. Jakarta: WHO Indonesia.

Widiyasari, E., Shaluhiyah, Z. \& Margawati, A. 2014. Implementasi Integrasi Program Prevention of Mother to Child HIV Transmission (PMTCT) dengan Layanan Antenatal di Puskesmas Wilayah Kota Surabaya. Manajemen Kesehatan Indonesia, 2(1), pp. 10-18.

Wudineh, \& Damtew, B. 2016. Mother-to-Child Transmission of HIV Infection and Its Determinants among Exposed Infants on Care and Follow-Up in Dire Dawa City, Eastern Ethiopia. AIDS Research and Treatment, 2016 